\title{
Evaluation of Sweet Potato Cultivars to the Formation of Sugars with Potential for the Production of Ethanol
}

\author{
Stroparo, E. C.; Knob, A.; de Resende, J. T. V.; Schirmer, W. N.; de Souza, \\ K. V.; Martins, K. G.
}

Rev. Virtual Quim., 2019, 11 (3), 605-615. Data de publicação na Web: 3 de junho de 2019

http://rvq.sbq.org.br

\section{Otimização do Processo de Hidrólise de Batata-doce a partir de Biocatalisadores Comerciais Visando Produção de Álcool}

Resumo: Atualmente, a produção de etanol a partir de fontes renováveis como o amido e resíduos lignocelulósicos tem sido extensamente investigado. Visando a maior viabilidade da produção de álcool a partir de amiláceas, objetivou-se otimizar a hidrólise de batata-doce utilizando biocatalisadores comerciais. A otimização foi conduzida a partir de $1 \mathrm{~g}$ do clone UGA $5 \mathrm{em} \mathrm{pH} 5,6,60^{\circ} \mathrm{Ce}$ tempo de 120 minutos. A evolução do processo enzimático foi avaliada em função de diferentes combinações de concentrações entre as enzimas comerciais $\alpha$-amilase de Bacillus sp. e amiloglucosidase de A. niger. Para cada ensaio foram determinadas as concentrações de açúcares redutores e glicose. Visando o ótimo operacional foi calculada uma análise de variância (ANOVA) com delineamento inteiramente casualizado em um planejamento fatorial $2 \times 5 \times 5$. Conforme o resultado de interação, apresentado pela ANOVA verificou-se que existe sinergismo significativo entre as enzimas na geração de açúcares redutores. A combinação $A 3$ revelou elevada taxa de conversão $(0,96 \pm 0,02 \mathrm{~g})$ a qual foi selecionada para os demais clones. Em condições otimizadas as melhores taxas de coversão corresponderam ao clone UGA56 onde obteve-se 0,97 $\pm 0,03 \mathrm{~g}$ de açúcares redutores e 0,89 $\pm 0,02 \mathrm{~g}$ de glicose. No entanto, este clone foi que apresentou menor produtividade $\left(\mathrm{t} \mathrm{ha}^{-1}\right)$, indicando que este parâmetro não é eficiente para discriminar o rendimento visando a produção de álcool.

Palavras-chave: Biomassa; amido; sacarificação; ANOVA.

\begin{abstract}
Currently, the etanol production from renewable sources, such as starch or lignocellulosic materials has been extensively investigated. Aiming at creating viability to the production of alcohol from starch raw material, this study was an attempt to optimize the sweet potato hydrolysis employing commercial biocatalysts. The hydrolytic procedure was developed from $1 \mathrm{~g}$ to access Unicentro / Guarapuava / Agronomy 5 (UGA 5) at pH 5.6, $60^{\circ} \mathrm{C}$ for 120 minutes. The enzymatic process evolution was evaluated as a function of different concentration combinations between the commercial enzymes $\alpha$-amylase from Bacillus sp. and amyloglucosidase from Aspergillus niger. In each test, the concentration of reducing sugars and glycose were determined. Aiming at the optimal operational, analysis of variance (ANOVA) was performed with a completely randomized design in a $2 \times 5 \times 5$ full factorial. According to the interaction result presented by the ANOVA, it was seen that there is significant synergy between the enzymes in the generation of reducing sugars. The combination A3 revealed high conversion rate $(0.96 \pm 0.02 \mathrm{~g})$ which was selected for the other accesses. The best conversion rates corresponded to the access UGA 56, in which $0.97 \pm 0.03 \mathrm{~g}$ reducing sugars and $0.89 \pm 0.02 \mathrm{~g}$ glycose were obtained. Despite this lowest productivity $\left(\mathrm{t} \mathrm{ha}^{-1}\right)$, this access indicating that this parameter is not enough to discriminate yield aiming at alcohol production.
\end{abstract}

Keywords: Biomass; starch; saccharification; reducing sugars; ANOVA.

\footnotetext{
* Universidade Estadual do Centro Oeste, Departamento de Engenharia Ambiental, campus Irati, BR 153 Km 7, s/n, Riozinho, CEP 84500-000, Irati-PR, Brasil.

$M$ stroparo.erivelton@gmail.com DOI: 10.21577/1984-6835.20190046
} 


\title{
Evaluation of Sweet Potato Cultivars to the Formation of Sugars with Potential for the Production of Ethanol \\ Erivelton César Stroparo, ${ }^{\mathrm{a}, *}$ Adriana Knob, ${ }^{\mathrm{b}}$ Juliano Tadeu Vilela de Resende, ${ }^{b}$ Waldir Nagel Schirmer, ${ }^{a}$ Kely Viviane de Souza, ${ }^{a}$ Kelly Geronazzo Martins ${ }^{\mathrm{a}}$
}

\begin{abstract}
a Universidade Estadual do Centro Oeste, Departamento de Engenharia Ambiental, campus Irati, BR 153, Km 7, s/n, Riozinho, CEP 84500-000, Irati-PR, Brasil.

${ }^{\mathrm{b}}$ Universidade Estadual do Centro Oeste, Departamento de Ciências Biológicas, campus Cedeteg, R. Simeão Varela de Sá 03, Vila Carli, CEP 85040-080, Guarapuava-PR, Brasil.

' Universidade Estadual do Centro Oeste, Departamento de Agronomia, campus Cedeteg, R. Simeão Varela de Sá 03, Vila Carli, CEP 85040-080, Guarapuava-PR, Brasil.
\end{abstract}

\section{*stroparo.erivelton@gmail.com}

Recebido em 20 de abril de 2018. Aceito para publicação em 25 de abril de 2019

1. Introduction

2. Material and Methods

2.1. Raw material selection

2.2. Optimization of the UGA5 access hydrolysis process using commercial enzymes

2.3. Determination of reducing sugars

2.4. Glycose determination

2.5. Data analysis and sampling design

\section{Results and Discussion}

3.1. UGA7; UGA64; UGA56 and UGA49 access hydrolysis process

\section{Final Considerations}

\section{Introduction}

Oil (a non-renewable natural resource) is still the world's main energy matrix. The pollution $\left(\mathrm{CO}_{2}\right.$ emission responsible for the greenhouse effect intensification) generated by its extraction, transportation, processing and when its byproducts are burnt, is considered a great disadvantage of using this kind of energy. In such context, new sources have been searched, mainly renewable ones. ${ }^{1}$

Regarding environmental issues, the alcohol - produced from sugars, starch or lignocellulosic biomass (second-generation) has been recognized worldwide as a promising source, since it presents potential to partially substitute gasoline. $^{2}$ 
Although nowadays most of the ethanol produced in the world is from sugar cane and sweet corn, projections indicate the need for alternative raw materials (starchy, agriculture and forestry residues) to meet this biofuel demand. ${ }^{3}$ Sweet potato (Ipomoea batatas) appears as an interesting alternative. Some characteristics of using this starchy based material are: short development cycle (4-5 months), rusticity in the field, adaptation to the weather conditions, high yield per ton of raw material and use of the byproduct resulting from its fermentation in animal food, since the sweet potato concentrates around $23 \%$ protein in its composition. ${ }^{4}$

However, one of the main technological constraints hampering the use of sweet potato as a viable and safe substrate to produce alcohol is its hydrolysis process (saccharification), since the highest carbohydrate concentration is in starchy form, therefore, a pre-treatment is necessary to convert the starch into fermentable sugars. ${ }^{5}$

Starch saccharification can occur through acid or enzymatic processes. The former presents as its main advantage the short conversion time, however, it has disadvantages as the need for the reactional medium neutralization, equipment corrosion and the generation of non-fermentative sugars. $^{6-7} \quad$ The starch enzymatic saccharification process usually occurs in conversion reactors with the use of enzymes (biocatalysts) which might be of vegetable or microbial origin. ${ }^{8}$

Amylases are classified according to their action mechanism on the starch or regarding the kind of linkage they hydrolyze. Regarding the action mechanisms, there are two categories: endoamylases and exoamylases. ${ }^{9}$ The endoamylases hydrolyze starch randomly inside its molecules, forming linear branches of oligosaccharides of different lengths and in this way they break the glycosidic linkages $\alpha$ 1,4 present inside (endo) the amylase or amylopectin chains. While the exoamylases act externally on the substrate linkages from the non-reducing ends, producing low molecular weight products. ${ }^{10}$
The $\alpha$-amylase hydrolyzes the polysaccharide linkages which have three or more D-glycose units in $\alpha-1,4$ union. The attack (non-selective) occurs on the several points of the chain simultaneously, forming initially oligosaccharides from five to seven glycose units, presenting the configuration $\alpha$ in the carbon $C$, in the reducing glycose unit produced. ${ }^{11}$ Most of the $\alpha$-amylases are able to contour the $\alpha-1,6$ linkages found in the branching points without breaking them.

The amyloglucosidases or glucoamylases break the amylose and amylopectin $\alpha-1,4$ linkages, forming $\beta$-D-glycose as a product. Some amyloglucosidases are able to hydrolyze type $\alpha-1,6$ glycosidic linkages, however, more slowly than the $\alpha-1,4$ linkage hydrolysis. Besides the starch amylose and amylopectin fractions, other molecules such as maltase, dextrin and glycogen are hydrolyzed by this biocatalyst, which might also act upon $\alpha-1,3$ linkages. ${ }^{11}$

It seems important to highlight that the amyloglucosidase plays the main role in natura starch hydrolysis and, when associated to $\alpha$-amylase, reveals great synergic effect. ${ }^{12}$ Enzyme mixtures containing $\alpha$-amylases and amyloglucosidase are more effective regarding starch hydrolysis. ${ }^{13}$

Although the enzymatic hydrolysis has been consolidated as the most effective procedure to convert starch into fermentable sugars, its economic viability is strongly hampered by the cost of the enzymes employed in the biomass hydrolysis process. ${ }^{14}$ In addition, the use of these biocatalysts during the process requires high temperatures, which make the process even less viable.

The hydrolysis of starchy raw materials, including sweet potato, to provide fermentable sugars and their bioconversion into lactic acid and bioethanol were recently reported ${ }^{15-16}$. However, there is still the need for establishing a better defined biological approach to convert sweet potato starch, evaluating the enzymes and the most suitable processing conditions to produce fermentable sugars. ${ }^{4}$ 
Therefore, the objective of this study was to evaluate the sweet potato access hydrolysis best conditions (enzyme concentration) using commercial biocatalysts.

\section{Material and Methods}

\subsection{Raw material selection}

Sweet potato Accesses coming from the Germplasm Banks of the State University of Centro Oeste (UNICENTRO) and the Federal University of Tocantins (UFT) (UGA5 and UGA7) were selected for the hydrolysis process due to their productivity (all roots harvested in $\mathrm{t} \mathrm{ha}^{-1}$ ) and their average mass (ratio between the root total mass $(\mathrm{g}$ ) and the number of roots with high nutrient concentration), see Table 1.

Table 1. Productivity and average mass of different sweet potato accesses

\begin{tabular}{ccc}
\hline \multirow{2}{*}{ Access } & \multicolumn{2}{c}{ ROOTS } \\
\cline { 2 - 3 } & PRODUCTIVITY $\left(\mathrm{t} \mathrm{ha}^{-1}\right)$ & AVERAGE MASS $(\mathrm{g})$ \\
\hline UGA5 & 62.01 & 360 \\
UGA7 & 56.70 & 440 \\
UGA64 & 50.88 & 330 \\
UGA56 & 16.68 & 140 \\
UGA49 & 41.50 & 690 \\
\hline
\end{tabular}

*UGA - Unicentro/Guarapuava/Agronomy

All the roots in the access were washed, processed, dried and ground (Figure 1). A digital oven with continuous air flow was used for drying, at $60^{\circ} \mathrm{C}$ constant temperature for
24 hours. Finally, the processed and dried tuberous roots were milled in a Wiley type mill, passed through $1.0 \mathrm{~mm}$ (20 mesh).

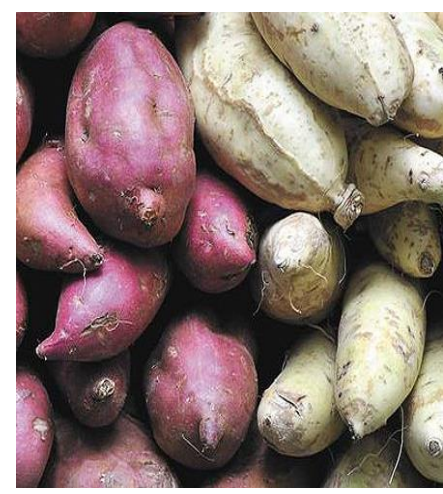

(a)

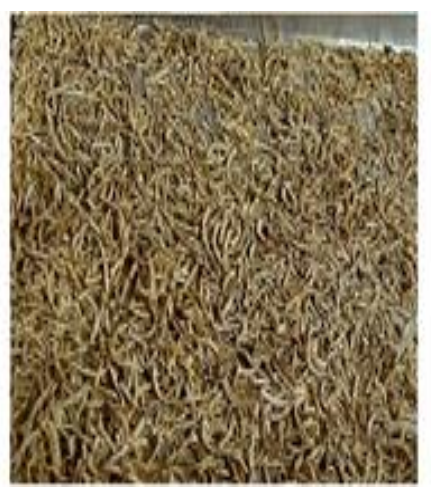

(b)

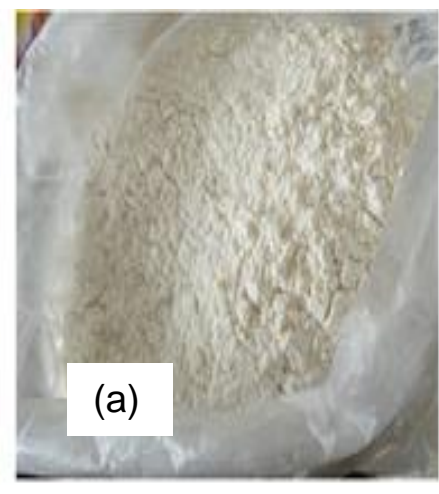

(c)

Figure 1. (a) in natura sweet potato; (b) after grated and dried, (c) after the grinding process 
2.2. Optimization of the UGA5 access hydrolysis process using commercial enzymes

The UGA5 access was previously selected for the hydrolysis process optimization, since its productivity levels $\left(\mathrm{t} \mathrm{ha}^{-1}\right)$ were higher than the remaining clones (Table 1). Initially, the enzymatic process evolution was evaluated as a function of different combinations between the commercial enzymes $\alpha$-amylase from Bacillus sp. (Sigma-Aldrich) and amyloglucosidase from $A$. niger (SigmaAldrich). The hydrolysis temperature and the medium $\mathrm{pH}$ were $60^{\circ} \mathrm{C}$ and 5.6, respectively, for a period of 2 hours. According to the enzyme manufacturer's instructions, the $\mathrm{pH}$ range for ?-amylase and amyloglucosidase activities are 5.0-7.5 and 4.5-6.0, respectively. For this reason, an intermediate $\mathrm{pH}$ value of 5.6 was adopted.

In all tests, a $1 \mathrm{~g}$ sample was incubated in Mcllvaine buffer, with the addition of different volumes of enzymes, so that the total reactional volume $20 \mathrm{~mL}$ was reached. Table 2 presents the enzyme combinations for each gram of substrate to be hydrolyzed as well as their respective volumes.

Table 2. Combinations of enzymes used in the UGA5 hydrolysis process

\begin{tabular}{cccccc}
\hline $\boldsymbol{\alpha}$-Amylase & $\mathbf{U g}^{-1}$ sample & $\begin{array}{c}\text { Volume } \\
(\boldsymbol{\mu L})\end{array}$ & $\begin{array}{c}\text { Amyloglucosidase } \\
\mathrm{Ug}^{-1} \text { sample }\end{array}$ & $\begin{array}{c}\text { Volume } \\
(\boldsymbol{\mu L})\end{array}$ \\
\hline A & 0.5 & 13 & $\mathbf{1}$ & 250 & 19 \\
B & 1.0 & 26 & $\mathbf{2}$ & 500 & 38 \\
C & 1.5 & 39 & $\mathbf{3}$ & 750 & 57 \\
D & 3.0 & 78 & $\mathbf{4}$ & 1500 & 114 \\
E & 6.0 & 156 & $\mathbf{5}$ & 2000 & 150 \\
\hline
\end{tabular}

All the enzyme combinations were evaluated, that is, $A 1$ to $A 5$. The same sequences were evaluated in relation to $B, C$, $\mathrm{D}$ and $\mathrm{E}$. All the tests were carried out in triplicate.

\subsection{Determination of reducing sugars}

The reducing sugars dosage was carried out through the DNS (3,5-dinitrosalicylic acid) method, proposed by Miller. ${ }^{17}$ The reactional solution had $250 \mu \mathrm{L}$ sample and $250 \mu \mathrm{L}$ DNS reagent. After homogenization for 5 minutes in bathwater, the solution was cooled in water and diluted with $2.5 \mathrm{~mL}$ distilled water. The spectrophotometer reading was carried out at $540 \mathrm{~nm}$. The absorbance value conversion into $\mathrm{mg}$ of reducing sugars was carried out through the glycose calibration curve with a 99,9\% correlation coefficient reliability.

\subsection{Glycose determination}

The amount of glycose generated in the sweet potato hydrolysis process was determined through the glycose oxidase method, employing the oxidase enzymatic kit (Laborlab). The reaction solution had $20 \mu \mathrm{L}$ of the hydrolyzed conveniently diluted in $2.0 \mathrm{~mL}$ of the work reactive. After incubation of the reaction mixture at $37{ }^{\circ} \mathrm{C}$ for 10 minutes, the absorbance reading was carried out in spectrophotometer at $505 \mathrm{~nm}$.

\subsection{Data analysis and sampling design}

In order to describe the system under study and consequently explore the best experimental conditions aiming at the optimal operational, the analysis of variance (ANOVA) 
with a completely randomized design in full factorial $2 \times 5 \times 5$ was developed. The differences between averages were ensured by the Fisher LSD $(P<0.05)$ test.

After the establishment of the best conditions for UGA5 clone hydrolysis process, the same procedure was carried out for the remaining clones. In order to determine the clone with the highest potential aiming at ethanol production, a one-way ANOVA (cultivar) was calculated, the dependent variables were reducing sugars and glycose. Next, the Fisher LSD $(P<0.05)$ test was used to ensure the differences between averages.

The residue normality and variance homogeneity were verified through the Shapiro-Wilks and Bartlett tests. ${ }^{18}$ The analyses were carried out aided by the program SAS/STAT 9.13.

\section{Results and Discussion}

The enzymatic hydrolysis of UGA5 clone was evaluated as a function of different combinations between the commercial enzymes $\alpha$-amylase and amyloglucosidase. The assays were performed at $60^{\circ} \mathrm{C}$ and $\mathrm{pH}$ 5.6. Although not evaluated in the current study, the relevance of reactional $\mathrm{pH}$ in sweet potato hydrolysis seems to be significant, since changes of $\mathrm{pH}$ may result in the loss of enzyme activity or dissociation between substrate and catalytic group of enzyme active center, leading to the reduced speed of enzymatic reaction. ${ }^{20}$ According to the interaction result, - there is significant synergism between the enzymes under study in the production of reducing sugars, since the $F$ test showed significant differences among averages $((F(4,16)=6,17 ; p<.001)$.
After the seventy-five tests had been completed (combining $\alpha$-amylases $A$ to $E$ with amyloglucosidase 1 to 5 , all in triplicate), it was seen, as shown in Table 3 , that the combinations E4 $(1,0 \pm 0,05 \mathrm{~g})$, D5 $(1,0 \pm 0,08$ g), D3 $(1,0 \pm 0,08 \mathrm{~g}), \mathrm{C5}(0,98 \pm 1,1 \mathrm{~g})$ and $\mathrm{A} 3$ $(0,95 \pm 0,02 \mathrm{~g})$ were the best generators of reducing sugars, while the worst combinations were $\mathrm{C} 1(0,58), \mathrm{B} 1(0,59)$ and $\mathrm{D} 2$ $(0,64)$. From the results, it is possible to infer that the effect of amyloglucosidase dosage was more critical than that of -amylase. In this case, high amyloglucosidase concentration was required for achieve efficient hydrolysis. This fact can occur since this enzyme hydrolyzes not only $\alpha-1,4$ glucosidic linkages, but also $\alpha-1,6$ glucosidic linkages, providing the ability to completely digest starch into glucose. ${ }^{19}$

Due to the enzymes high cost and the small variation of reducing sugars obtained at the end of the process, the combination $\mathrm{A} 3$ was selected $\left(0.5 \mathrm{U} \mathrm{g}^{-1}\right.$ amyloglucosidase and 750 $U \mathrm{~g}^{-1} \alpha$-amylase), because of the smallest volumes of enzymes used, which, consequently, can imply in significant cost reduction in larger scale applications.

The combined use of enzymes allowed high conversion rates $(0,96 \pm 0,02 \mathrm{~g})$ of the starchy material into fermentable sugars to be obtained. This was due to the $\alpha$-amylase dextrinizant activity, which breaks the starch into smaller molecules (dextrins, while the amyloglucosidase hydrolyzes the dextrin molecules and starch through the nonreducing ends, producing glycose units. It seems relevant to emphasize that this enzyme is the only one able to hydrolyze simultaneously the starch molecule linkages $\alpha-1,4$ and $\alpha-1,6$ in glycose. ${ }^{21}$ 
Table 3. Average of reducing sugars generated through different combinations of $\alpha$-amylases and Amyloglucosidase

\begin{tabular}{|c|c|c|c|}
\hline$\alpha$-amylases & Amyloglucosidase & Reducing sugars (g) & Group \\
\hline C & 1 & 0.58 & $f$ \\
\hline B & 1 & 0.59 & $f$ \\
\hline D & 2 & 0.64 & $f$ \\
\hline B & 2 & 0.66 & ef \\
\hline B & 4 & 0.67 & ef \\
\hline D & 1 & 0.67 & ef \\
\hline $\mathrm{E}$ & 1 & 0.68 & def \\
\hline A & 1 & 0.70 & def \\
\hline B & 3 & 0.71 & def \\
\hline C & 2 & 0.72 & def \\
\hline A & 2 & 0.78 & cde \\
\hline C & 3 & 0.80 & cde \\
\hline C & 4 & 0.81 & bcd \\
\hline $\mathrm{E}$ & 2 & 0.86 & $a b c$ \\
\hline $\mathrm{E}$ & 5 & 0.86 & $a b c$ \\
\hline D & 4 & 0.87 & $a b c$ \\
\hline A & 4 & 0.89 & $a b c$ \\
\hline E & 3 & 0.90 & $a b c$ \\
\hline A & 5 & 0.90 & $a b c$ \\
\hline B & 5 & 0.93 & $a b c$ \\
\hline A & 3 & 0.95 & a \\
\hline C & 5 & 0.98 & a \\
\hline D & 3 & 1.00 & a \\
\hline D & 5 & 1.00 & $a$ \\
\hline$E$ & 4 & 1.00 & $a$ \\
\hline
\end{tabular}

Averages followed by the same letter did not differ statistically in the Tukey test at $5 \%$ significance

The best enzyme concentrations established by Yingling ${ }^{22}$ to promote sweet potato hydrolysis were $214 \mathrm{U} \mathrm{g} \mathrm{g}^{-1}$ for $\alpha$ amylase and $398 \mathrm{U} \mathrm{g}^{-1}$ for amyloglucosidase, obtaining starch conversion rates slightly lower than the ones found in this study, equivalent to $92.5 \%$. Similar results were found by Shanavas ${ }^{23}$ with manioc flour. When using $\alpha$-amylase and amyloglucosidase in the hydrolysis of sweet potato starch, Souza, ${ }^{24}$ found out that the enzyme concentrations corresponded to $12.71 \mathrm{U} \mathrm{g}^{-1}$ (Termamyl) and $101.1 \mathrm{U} \mathrm{g}^{-1}$ (AMG-300L). This suggests that the differences observed in relation to the 
combination of enzymes established in this study are probably due to the different nature of the accesses under analysis.

3.1. UGA7; UGA64; UGA56 and UGA49 access hydrolysis process

Based on best enzymes concentrations for UGA5 access hydrolysis, which corresponded to the combination $A 3$, allied to the reaction time of 120 minutes, the hydrolysis of the remaining clones was carried out.
Figure 2 shows that the highest levels, both of reducing sugars and glycose were produced from the clone UGA56, in which $0.97 \pm 0.03 \mathrm{~g}$ reducing sugars and $0.89 \pm 0.02 \mathrm{~g}$ glycose were obtained from $1.0 \mathrm{~g}$ starch. However, this clone revealed the lowest productivity indices $\left(t \mathrm{ha}^{-1}\right.$ ) (Table 1). Therefore, these clones productivity was not an efficient parameter to discriminate yield aiming at alcohol production. Good levels regarding reducing sugars were also reached with the accesses UGA5 and UGA64, corresponding to $0.95 \pm$ $0.02 \mathrm{~g}$ and $0.94 \pm 0.02 \mathrm{~g}$, respectively, which were statistically different. However, UGA 49 was the one with the lowest reducing sugar and glycose averages.
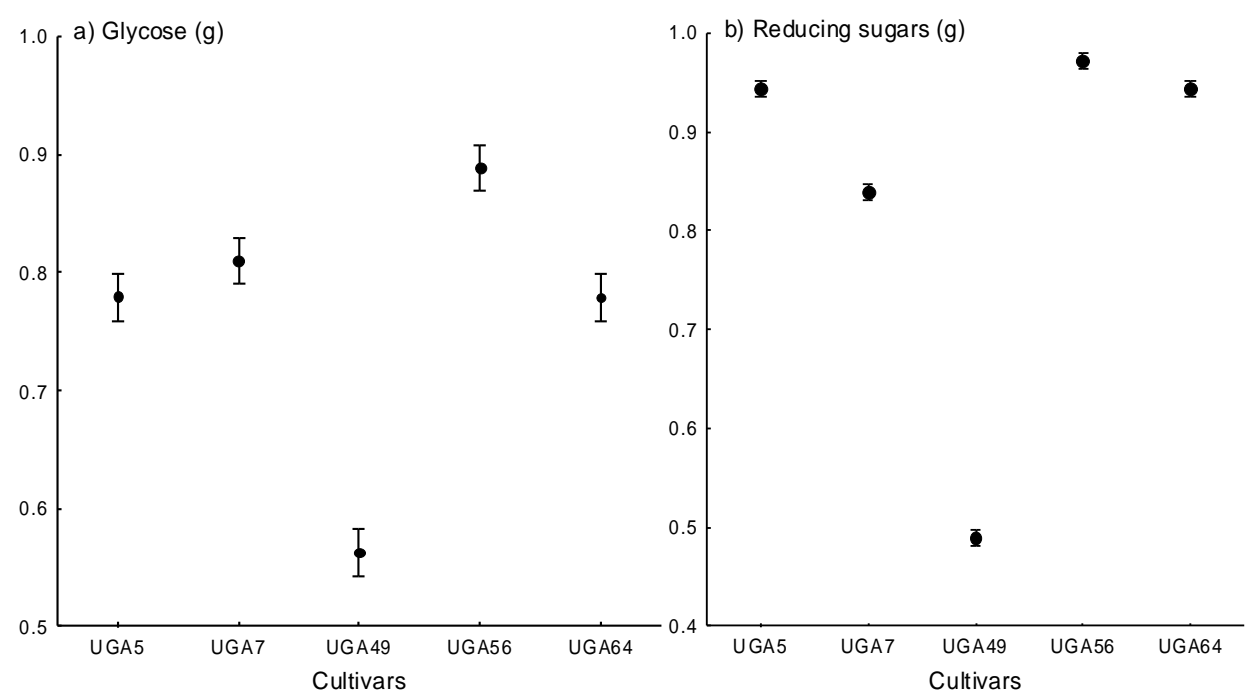

Figure 2. Hydrolysis of UGA7; UGA64; UGA56 and UGA49 access using commercial enzymes

Kansou $^{25}$ explained that the amount of sugars generated in the hydrolytic process is directly proportional to the starch percentage present in the sweet potato. These authors also pointed out that the starch percentage depends on the amylacea cultivation time. The longer the cultivation time is, the higher the levels of starch generated by the plant are. Therefore, UGA56 clone is expected to have had initially higher starch content than the remaining accesses.

From the quantification of the glycose present in $1.0 \mathrm{~g}$ hydrolyzed sweet potato, it was possible to calculate theoretically the amount of alcohol generated through the Gay-Lussac equation, which can be used as a reference for efficacy calculations regarding the alcohol to be produced.

$$
\mathrm{C}_{6} \mathrm{H}_{12} \mathrm{O}_{6(\mathrm{~s})} \rightarrow 2 \mathrm{C}_{2} \mathrm{H}_{5} \mathrm{OH}_{(\mathrm{l})}+2 \mathrm{CO}_{2(\mathrm{~g})}
$$


Therefore, from $0.89 \mathrm{~g}$ glycose, it would be possible to obtain stoichiometrically $0.45 \mathrm{~g}$ ethanol or $0.57 \mathrm{~mL}$ ethanol. However, despite the working conditions rigor, it is important to emphasize that a decrease in the amount of alcohol obtained at the end of the process was observed, due to possible experimental errors, both in the hydrolytic process and in fermentation, as well as part of the sugars (around $5 \%$ ) being destined to the cell growth and the formation of fermentation byproducts, such as glycerol, succinic acid, etc.

The alcohol production estimates for the remaining accesses is shown in Table 4.

Table 4. Estimates of alcohol production by the remaining accesses via Gay-Lussac equation

\begin{tabular}{ccc}
\hline Access & Glycose (g) & Alcohol $(\mathrm{mL})$ \\
\hline UGA5 & $0.78 \pm 0.01$ & $0.51 \pm 0.01$ \\
UGA7 & $0.80 \pm 0.02$ & $0.52 \pm 0.02$ \\
UGA49 & $0.59 \pm 0.02$ & $0.38 \pm 0.02$ \\
UGA56 & $0.89 \pm 0.02$ & $0.57 \pm 0, .02$ \\
UGA64 & $0.77 \pm 0.02$ & $0.50 \pm 0.02$ \\
\hline
\end{tabular}

Although access UGA5 presented the highest productivity index in the field, other accesses with lower indices were shown suitable for the production of alcohol regarding fermentable sugars. Therefore, it was seen that the productivity index alone is not an indication of excellence regarding alcohol generation from sweet potato.

\section{Final Considerations}

In the present study, we established a combination of $\alpha$-amylases and amyloglucosidases that presented great efficacy in converting sweet potato starch into fermentable sugars. Data indicated the effect of amyloglucosidase dosage on the hydrolysis of sweet potato starch was more critical than that of $\alpha$-amylase.

It seems relevant to highlight that clones with low productivity indices $\left(\mathrm{t} \mathrm{ha} \mathrm{H}^{-1}\right)$, such as UGA56, revealed excellent results regarding alcohol generation. Finally, it is emphasized that important aspects need to be evaluated, such as $\mathrm{pH}$, temperature and the reaction kinetics, in addition to studies of the optimal fermentation conditions for this kind of raw material.

\section{References}

${ }^{1}$ Mesaric, P.; Krajcar, S. Home demand side management integrated with electric vehicles and renewable energy sources. Energy and Buildings 2015, 108, 1. [CrossRef]

${ }^{2}$ Khatiwada, D.; Leduc, S.; Silveira, S.; McCallum, I. Optimizing ethanol and bioelectricity production in sugarcane biorefineries in Brazil. Renewable Energy 2016, 85, 371. [CrossRef]

${ }^{3}$ Zhang, L.; Chen, Q.; Jin, Y.; Xue, H.; Guan, J.; Wang, Z.; Zhao, H. Energy-saving direct ethanol production from viscosity reduction mash of sweet potato at very high gravity (VHG). Fuel Processing Technology 2010, 91, 1845. [CrossRef]

${ }^{4}$ Duvernay, W. H.; Chinn, M. S.; Yencho, G. C. Hydrolysis and fermentation of sweet potatoes for production of fermentable sugars and ethanol. Industrial Crops and Products 2013, 42, 527. [CrossRef]

${ }^{5}$ Girard, P.; Fallot, A. Review of existing and emerging technologies for the production of 
biofuels in developing countries. Energy for Sustainable Development 2006, 10, 92. [CrossRef]

${ }^{6}$ Hashem, M.; Darwish, S. M. I. Production of bioethanol and associated by-products from potato starch residue stream by Saccharomyces cerevisiae. Biomass and Bioenergy 2010, 34, 953. [CrossRef]

7 Betiku, E.; Akindolani, O. O.; Ismaila, A. R. Enzymatic hydrolysis optimization of sweet potato (Ipomoea batatas) peel using a statistical approach. Brazilian Journal of Chemical Engineering 2013, 30,467. [CrossRef]

${ }^{8}$ Santos, J. R. A.; Lucena, M. S.; Gusmão, N. B.; Gouveia, E. R. Optimization of ethanol production by Saccharomyces cerevisiae UFPEDA 1238 in simultaneous saccharification and fermentation of delignified sugarcane bagasse. Industrial Crops and Products 2012, 36, 584. [CrossRef]

${ }^{9}$ López, J. A.; Lázaro, C. C.; Castilho, L. R, Freire, D. M. G, de Castro, A. M. Characterization of multienzyme solutions produced by solid-state fermentation of babassu cake, for use in cold hydrolysis of raw biomass. Biochemical Engineering Journal 2013, 77, 231. [CrossRef]

${ }^{10}$ Costa, S. T. C.; Abreu-Lima, T. L.; Carreiro, S. C. Atividade amilolítica de leveduras isoladas de batata-doce (Ipomoea batatas (L.) Lam). Revista Biociências Unitau 2011, 17, 15. [Link]

${ }^{11}$ Spier, M. R.; Woiciechowski, A. L.; Vandenberghe, L. P. S.; Soccol, C. R. Production and characterization of amylases by Aspergillus niger under solid state fermentation using agro industrials products. International Journal of Food Engineering 2006, 2, 1. [CrossRef]

${ }^{12}$ Man, J.; Yang, Y.; Huang, J.; Zhang, C.; Zhang, F.; Wang, Y.; Gu, M.; Wei, C. Morphology and structural properties of highamylose rice starch residues hydrolyzed by amyloglucosidase. Food Chemistry 2013, 138 , 2089. [CrossRef] [PubMed]

${ }^{13}$ Ruiz, M. I.; Sanchez, C. I.; Torrres, R. G.; Molina, D. R. Enzymatic hydrolysis of cassava starch for production of bioethanol with a Colombian wild yeast strain. Journal of the Brazilian Chemical Society 2011, 22, 2337. [CrossRef]

${ }^{14}$ Farinas, C. S.; Lemo, V.; Rodríguez-Zúñiga, U. F.; Neto, V. B.; Couri, S. Avaliação de diferentes resíduos agroindustriais como substratos para a produção de celulases por fermentação semi-sólida. available in: https://www.infoteca.cnptia.embrapa.br/bits tream/doc/31744/1/BPD222008.pdf>. Access on: April 15, 2018.

${ }^{15}$ Adthalungrong, A.; Adthalungrong, C.; Kumnil, P. Simultaneous saccharification and fermentation for lactic acid production from sweet potato. KKU Research Journal 2014, 19, 116. [Link]

${ }^{16}$ Risso, R. S. Dissertação de Mestrado. Universidade Federal do Rio Grande do Sul, 2014. [Link]

17 Miller, G. L. Use of dinitrosalicylic acid reagent for determination of reducing sugar. Analytical Chemistry, 1959, 31, 426. [Link]

${ }^{18}$ Zar, J. H.; Biostatistical analysis, 4a. ed., Prentice-Hall: NJ, Upper Saddle River, 1999.

${ }^{19}$ Tanaka, A.; Takeda, S. Subsite Structure of Rhizopus Glucoamylase for the Hydrolytic Reaction of Isomaltooligosaccharides. Bioscience, Biotechnology, and Biochemistry 1994, 58, 1809. [CrossRef]

${ }^{20}$ Han, L.; Feng, J.; Zhang, S.; Ma, Z.; Wang, Y.; Zhang, $X$. Alkali pretreated of wheat straw and its enzymatic hydrolysis. Brazilian Journal of Microbiology 2012, 43, 53. [CrossRef]

${ }^{21}$ Torres, L. M.; Leonel, M.; Mischan, M. M. Concentração de enzimas amilolíticas na hidrólise do amido de gengibre. Ciência Rural 2012, 42, 1327. [CrossRef]

${ }^{22}$ Yingling, B.; Li, C.; Honglin, W.; Xiwen, Y.; Zongcheng, Y. Multi-objective optimization of bioethanol production during cold enzyme starch hydrolysis in very high gravity cassava mash. Bioresource Technology 2011, 102, 8077. [Crossref] [PubMed]

${ }^{23}$ Shanavas, S.; Padmaja, G.; Moorthy, S. N.; Sajeev, M. S.; Sheriff, J. T. Process optimization 
for bioethanol production from cassava starch using novel eco-friendly enzymes. Biomass and Bioenergy 2011, 35, 901. [CrossRef]

${ }^{24}$ De Souza, F. R.; da Silveira, M. A.; Botelho, A. F. Study and evaluation of alpha amylase and glucoamylase concentrations in sweet potato hydrolysis. Revista Sodebras 2013, 85, 3. [Link]

${ }^{25}$ Kansou, K.; Buléon, A.; Gérard, C.; RollandSabaté, A. Multivariate model to characterise relations between maize mutant starches and hydrolysis kinetics. Carbohydrate Polymers 2015, 133, 497. [Crossref] [PubMed] 